MINERALOGIA POLONICA

DOI 10.2478/v10002-007-0019-4

PL ISSN 0032-6267

Vol. 37, No 2, 2006

Alexander SMIRNOV1, Jaroslav PRŠEK ${ }^{2}$, Martin CHOVAN²

\title{
MINERALOGY AND GEOCHEMISTRY OF THE NIŽNÁ BOCA Sb-Au HYDROTHERMAL ORE DEPOSIT (WESTERN CARPATHIANS, SLOVAKIA)
}

\author{
Received April 04, 2007; accepted January 25, 2008
}

A b stract. Samples from hydrothermal Sb-Au mineralization in the area SE of Nižná Boca village in the Nízke Tatry Mountains were investigated using a variety of geochemical and mineralogical methods. Ore minerals typically occur in N-S striking quartz-carbonate veins hosted by an I-type biotite granodiorite to tonalite of Variscan Age (the Dumbier Type). Paragenetic associations in the deposit are comparable to other mineralizations of the same type in the Dumbierske Nízke Tatry Mountains. A quartz-arsenopyrite, pyrite stage of mineralization is the oldest with a calculated temperature of formation of about $445^{\circ} \mathrm{C}$. It is followed by a quartz-carbonate-stibnite, zinkenite stage and, in turn, a quartz-carbonate-sphalerite-galena, boulangerite-gold stage. The gold typically contains between 9-18 wt.\% Ag regardless of mineral association. No evidence for further generations of gold was found although it is possible that some gold was remobilized from the structure of the auriferous arsenopyrite. The Au and Ag content of the bulk ore ranges from 0.53 g.t $\mathrm{t}^{-1}$ to $20.2 \mathrm{~g} . \mathrm{t}^{-1}$ and from $0.9 \mathrm{~g} . \mathrm{t}^{-1}$ to $31.2 \mathrm{~g} . \mathrm{t}^{-1}$, respectively. A tetrahedrite-chalcopyrite stage is followed by a barite-hematite stage - the youngest assemblage in the deposit. Fluid inclusions from the first mineralization stage are usually less than $3 \mu \mathrm{m}$ in size and contain less than $3.6 \mathrm{wt} . \% \mathrm{CO}_{2}$; salinity, density and homogenization temperature range from $2.7-16.3 \mathrm{wt} . \% \mathrm{NaCl}_{(\mathrm{eq})}, 0.85-1.03 \mathrm{~g} . \mathrm{cm}^{-1}$ and $128-280^{\circ} \mathrm{C}$, respectively.

Key-words: hydrothermal ore, gold, Nízke Tatry, Nižná Boca, stibnite, sulphosalts, Western Carpathians

\section{INTRODUCTION}

The village of Nižná Boca is located on the northern slopes of the Ďumbierske Nízke Tatry Mts, approximately $10 \mathrm{~km}$ south of Liptovský Hrádok in Slovakia. The geographical coordinates of the village are $48^{\circ} 57^{\prime} 00^{\prime \prime} \mathrm{N}$ and $19^{\circ} 46^{\prime} 00^{\prime \prime} \mathrm{E}$.

Boca (there is no distinction between Nižná and Vyšná Boca villages in the archives) was an important centre of gold mining in the Nízke Tatry Mountain in what is

\footnotetext{
1 Department of Geosciences, State University of New York, Stony Brook, NY 11794-2100, USA.

2 Department of Mineralogy and Petrology, Faculty of Natural Sciences, Comenius University, Mlynská Dolina, 84215 Bratislava, Slovakia.
} 
present-day Slovakia. The oldest mention of mining in the Boca Valley comes from 1271 (Bergfest 1952). At first, the gold was only gleaned from placer mines in alluvial sands and gravels in the Boca River (north of the village). Only later was it mined underground directly from ore veins; more than 70 adits were reported by Volko-Starohorský (1949). Throughout its history, the income from mining there fluctuated between profits and losses. The annual gold production is estimated to have been 3-5 kg (Bergfest 1952; Slavkay 1988). The last reports of gold mining there are from the second half of the $19^{\text {th }}$ century (Bergfest 1952).

With the notable exception of the Chopec mining field, N-NW of Vyšná Boca Village (Ozdín, Chovan 1999), most of the gold mining activities were conducted in the area of the present-day Nižná Boca village where numerous traces of the mining (e.g. mine dumps, adits, surface explorations) are still visible to the SE of the village.

The occurrence of alluvial gold in the Boca River was recently evaluated by Smirnov (1999) and Smirnov and Chovan (2003). The geochemistry and mineralogy of the primary gold- and stibnite-bearing mineralization is the subject of this paper. As no such study of the Nižná Boca deposit has ever been published, we hope that this contribution will further the understanding of metallogenesis in the Nízke Tatry Mountains.

\section{GEOLOGICAL SETTING AND MINERALIZATION}

The surroundings of Nižná Boca village consist of two markedly different geological environments: the Tatric Unit to the $S$ of the village and the Hronic Unit - the Choč Nappe - to the N (Fig. 1). The contact between these units is sharp due to the fact that, during the Alpine Orogeny, the Hronic Unit was superimposed onto the lower Triassic (Scythian) quartzites of the Lúžna Formation enveloping the Tatric Unit (Biely 1992; Mišík, Jablonský 2000).

The Hronic Unit is represented by the Ipoltica Group and both its subunits: the Malužiná Group (Permian) and the Nižná Boca Group (Stephanian). The former contains fluvial-lacustrine redbeds interbedded with dolomites, evaporates and mafic lavas. The latter comprises turbiditic-, fluvial-, deltaic- and lacustrine sediments interbedded with layers of intermediate- to felsic volcanic rocks (Vozárová, Vozár 1988; Biely 1992; Dostal et al. 2003).

The Tatric Unit is represented in the area by the I-type biotitic granodiorite-tonalitethe Dumbier Type - of Variscan $(368 \pm 22 \mathrm{Ma}, \mathrm{Rb} / \mathrm{Sr})$ age. Macroscopically, the granitic rocks are fine- to medium grained and locally porphyritic. Plagioclase is the most abundant constituent, followed by quartz and biotite. Locally, the biotite crystals are preferentially oriented and form an apparent "layered" texture. Common accessories are zircon, apatite, zoisite and epidote (Lukáćik 1985; Biely 1992; Broska, Uher 2001). The crystallization temperature was calculated to be $690-730^{\circ} \mathrm{C}$ (Cambel et al. 1990). Metamorphic rocks occurring as xenoliths in the granitoid rocks are represented by markedly foliated gneisses with, in some cases, migmatitic textures. They comprise garnet, biotite, plagioclase, quartz, muscovite, kyanite and sillimanite with accessory ilmenite, zircon and apatite. The P-T conditions of retrograde metamorphosis were 


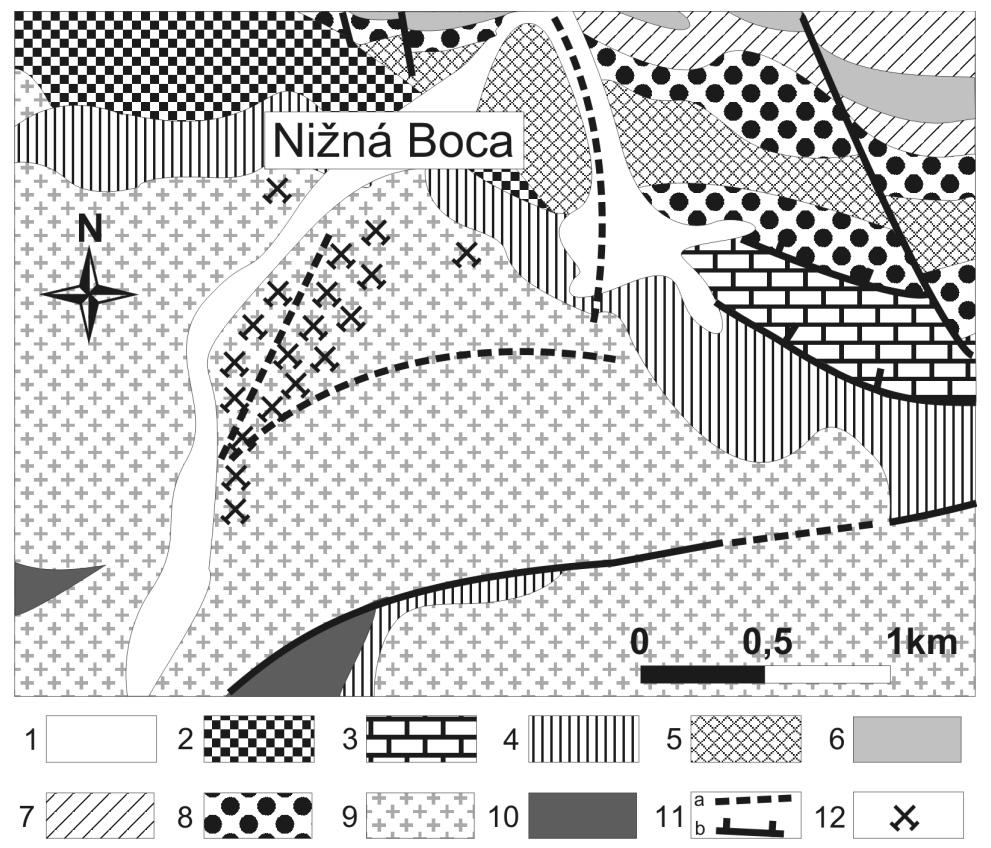

Fig. 1. Geological map of the Nižná Boca Area

1 - fluvial loams and gravel loams (Holocene), 2 - slope sediments, unclassified (Quaternary),

3 - marley and Calpionella limestones (Tithonian - Hauterivian), 4 - the Lúžna Formation, quartzites, quartz and arkose sandstones (Scythian), 5 - the Ipoltica Group, diorites (Permian), 6 - the Malužiná Formation, tuff and tuffites of the 1. megacycle (Autunian), 7 - the Malužiná Formation, breccias, sandstones, siltstones, shales, evaporites (Permian), 8 - the Nižná Boca Formation, grey breccias, sandstones, shales, dacites (Stephanian), 9 - biotite tonalites to granodiorites of the Ďumbier Type,

10 - biotite- to two-mica gneisses with banded texture, 11: a - Alpine nappe overthrust planes, $b$ - faults and tectonic boundaries, 12 - schematic depiction of mining activities. Adapted from (Biely 1992)

determined to be $620-660^{\circ} \mathrm{C}, 3.2-3.6 \mathrm{kbar}$ (garnet rim) and $730^{\circ} \mathrm{C}, 4 \mathrm{kbar}$ (garnet core) (Janák et al. 2000).

Occurrences of Sb-Au mineralization in the Tatric Unit of the Nízke Tatry Mts were extensively studied in the past, most notably those of Dúbrava (Chovan 1990; Chovan et al. 1995a; Chovan et al. 1998; Orvošová et al. 1998), Magurka (Chovan et al. 1995b; Bakos, Chovan 1999) and Mlynná Dolina (Majzlan, Chovan 1997). In the comprehensive review of Chovan et al., (1996), 10 discrete types of mineralization were identified, e.g., arsenopyrite-pyrite (frequently with "invisible" gold), gold (usually associated with quartz and sulphides) and antimony (typically associated with quartz, Sb-sulphosalts). More than one type of mineralization may occur in the same deposit.

The veins of hydrothermal Sb-Au at the Nižná Boca deposit are predominantly hosted by the Dumbier tonalite/granodiorite; metamorphic host rocks (e.g., biotitic paragneisses, migmatites) are rare. According to Koděra (1990), the hydrothermal $\mathrm{Au}-\mathrm{Sb}$ veins have a N-S strike and dip $50^{\circ}$ to the E. The most exploited vein - the Margaréta Vein - is $160 \mathrm{~m}$ long with an average thickness of 1.2-1.6 m (Slavkay 1988). Other ore bodies mentioned in the compilation of Slavkay (1988) are Pavol, Tobiáš, 
Witterman (Wilderman?), Daniel, Plawa-Dower, Hilfgottes, Weise Kluft, Kreutz Schlag and Wasch-Werck. The first mineralogical study available to us notes quartz and carbonates to be the dominant vein minerals with minor gold, Ag amalgam (?), stibnite, galena, chalcopyrite and pyrite (Tóth 1882). In addition, Slavkay (1988) noted sphalerite and tetrahedrite. Occurrences of Ni-Co ores originally described as in the Nižná Boca area (Bergfest 1952; Koděra 1990) actually occur to the SW (Helena) and NW (Bruchatý Grúnik) of the neighbouring village of Vyšná Boca (Ozdín, Chovan 1999).

\section{RESEARCH METHODOLOGY}

Prior to sample collection, reconnaissance field trips were conducted to map out the extent of the old mining activities. Samples collected from mine dumps were carefully examined for textural evidence of crystallization episodes. In total, 125 polished sections were prepared and inspected in polarized reflected light. Close attention was paid to ore structures and the relative age relationships of the ore minerals. The chemical compositions of the primary minerals (excepting the sulphosalts) were determined by electron probe microanalysis (EPMA) using a JEOL Superprobe 733 (Geological Survey of Slovak Republic, Bratislava, Slovakia) and a JEOL JXA 840A (Comenius University, Bratislava, Slovakia) using $20 \mathrm{kV}, 15 \mathrm{nA}$ and $2-5 \mu \mathrm{m}$ beam diameter. Standards were as follows: arsenopyrite $-\mathrm{Fe}, \mathrm{As}, \mathrm{S}$; $\mathrm{PbS}-\mathrm{Pb} ; \mathrm{HgS}-\mathrm{Hg}$; $\mathrm{Bi}, \mathrm{Sb}, \mathrm{Au}, \mathrm{Ag}, \mathrm{Zn}, \mathrm{Cu}$, Te as pure metals. Sulphosalts were analysed using a JEOL Superprobe 733 (Geologisk Institut, University of Copenhagen, Denmark) using $20 \mathrm{kV}, 20 \mathrm{nA}, 5 \mu \mathrm{m}$ beam diameter and the following standards: $\mathrm{PbS}-\mathrm{Pb} ; \mathrm{Bi}_{2} \mathrm{~S}_{3}-\mathrm{Bi} ; \mathrm{CuFeS}_{2}-\mathrm{S}, \mathrm{Cu}, \mathrm{Fe} ; \mathrm{Ag}$, $\mathrm{Sb}$ as pure metals.

Fe secondary minerals were analysed by X-ray diffraction (XRD) using a DRON-3 diffractometer (Comenius University, Bratislava, Slovakia) under the following conditions: $\mathrm{CuK} \alpha$ radiation, $\mathrm{Ni}$ filter, step $0.02,0.1^{\circ} \mathrm{pm}$. Arsenopyrite was analysed on a PHILIPS diffractometer (Slovak Academy of Sciences, Bratislava, Slovakia) using $\mathrm{CoK} \alpha$ radiation, no monochromator, step $0.02,2^{\circ} \mathrm{pm}$ with quartz as an internal standard. XRD analyses of Sb secondary minerals were performed using a STOE diffractometer (Masaryk University, Brno, Czech Republic) under the following conditions: $\mathrm{CuK \alpha}$ radiation, Ge crystal monochromator, PSD detector, step $0.01^{\circ}, 2^{\circ} \mathrm{pm}$. The Au content in arsenopyrite was determined using a Carl-Zeiss optical emission spectrometer (Slovak Academy of Sciences, Banská Bystrica, Slovakia) using a 7A current and $120 \mathrm{~s}$ exposition time.

The Au contents in bulk ore samples (0.1-1000 g.t $\left.\mathrm{t}^{-1}\right)$ were analysed using a VARIAN AA-20 flame atomic absorption spectrometer (Geoecological Laboratories Ltd., Spišská Nová Ves, Slovakia). Samples were dissolved in $\mathrm{HCl} / \mathrm{HNO}_{3}$ solution and analysed using an acetylene/air flame and selecting $\mathrm{Ag}$ and $\mathrm{Au}$ absorption bands at $328.1 \mathrm{~nm}$ and $242.8 \mathrm{~nm}$, respectively. Smaller concentrations $(0.005-0.1 \mathrm{~g} / \mathrm{t})$ of Au were analysed using a SPECTR AA-400 atomic absorption spectrometer with a GTA-96 electrothermic atomiser (Geoecological Laboratories Ltd., Spišská Nová Ves, Slovakia) under the following conditions: Au absorption band $=242.8 \mathrm{~nm}, T_{\text {combustion }}=600^{\circ} \mathrm{C}, T_{\text {atomization }}=$ $=2400^{\circ} \mathrm{C}$. 
The fluid inclusion study was performed using a microthermometric LINKAM THMS 600 (freezing - heating) stage coupled with a NIKON Optiphot-2 microscope (Geological Survey of Slovak Republic, Bratislava). A CCD camera coupled with a computer monitor enabled observations of phase transition in fluid inclusions as small as $\sim 3 \mu \mathrm{m}$. The microthermometric stage was calibrated using synthetic fluid inclusions and pure $\mathrm{K}_{2} \mathrm{Cr}_{2} \mathrm{O}_{7}$. The phase transitions measured in our samples were: total homogenization temperature $\left(T_{h}\right)$, eutectic temperature $\left(T_{e}\right)$ and the temperature of ice melting $\left(T_{\text {mice }}\right)$. The precision of the measurements was $\pm 0.1^{\circ} \mathrm{C}$.

\section{RESULTS}

A map of old mining activities in the Nižná Boca area, as confirmed by field reconnaissance is shown in Figure 2. Not all of the discovered traces of mining are

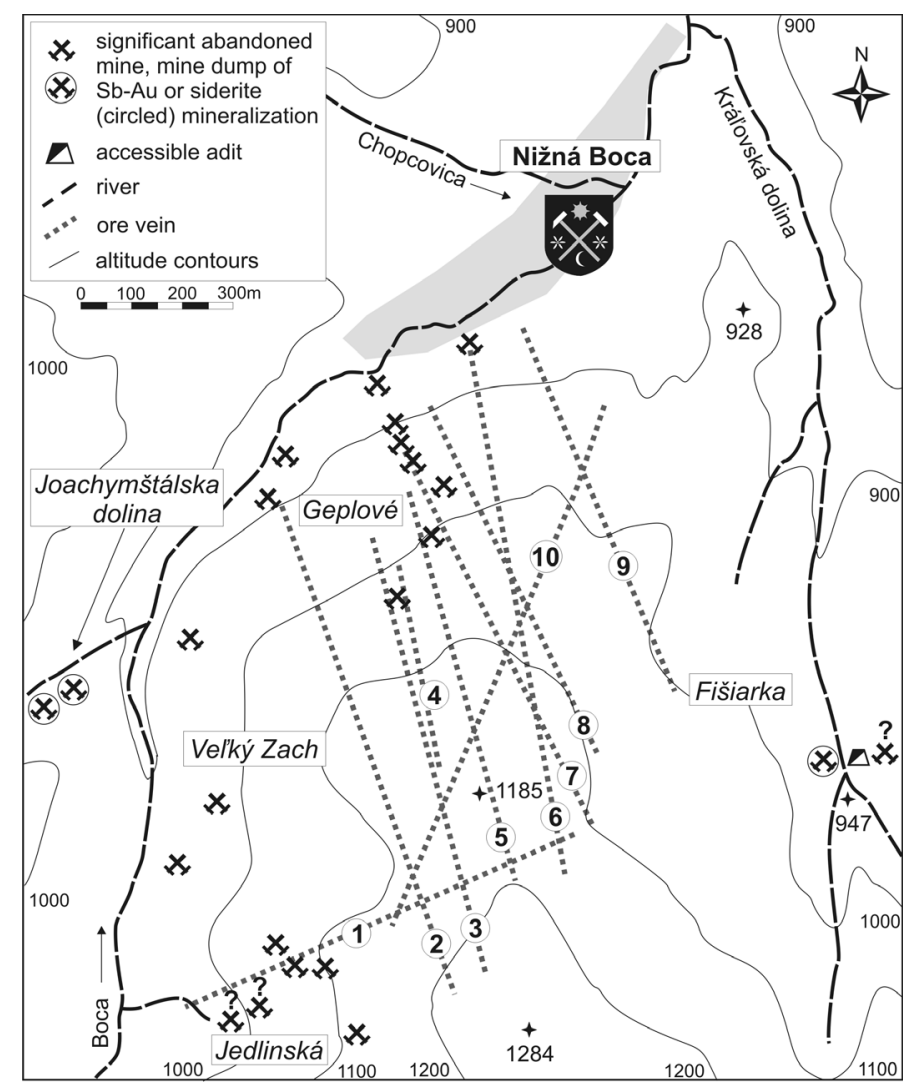

Fig. 2. A schematic depiction of mining activities in the Nižná Boca area. The names of ore veins are as follows: 1 - Weise Kluft, 2 - Tobiáš, 3 - Margaréta, 4 - Wittermann (Wilderman?) (misplaced), 5 - Wittermann (Wilderman?), 6 - Daniel, 7 - Hilfgottes, 8 - Plawa Dower, 9 - Wasch-Werck, 10 - Rosen Kranz. The occurrences of both Sb-Au and siderite mineralization types are shown. Ore vein positions adapted from Bergfest (1952) 
shown in the map, only prominent mine dumps. Based on the mineralogy of dump material, we conclude that $\mathrm{Sb}$-Au mineralization was predominantly exploited in the Zach and Geplové mining field. Several mine dumps with abundant siderite ore samples are located at Fišiarka in the Kralovská Dolina valley where the only accessible adit (Okrúhla štôlňa) in the Nižná Boca area was discovered. It is unclear whether the adit was dug for exploratory or exploitation purposes (total length $\sim 35 \mathrm{~m}$ ) as no signs of exploitable ore were found inside or near the adit. There are some surface exploration digs and mine dumps on the slope directly above the mine; however, excepting altered granitoid rocks with occasional disseminated arsenopyrite, pyrite and tetrahedrite, no ore samples were found. Though the increased presence of sedimentary quartzites of the Lúžna Formation in this area reflects the proximity of the stratigrafic boundary between the Tatric crystalline massif and its quartzite envelope, no ore veins intersecting the quartzites were found.

The NW-SW arrangement of old mining activities at Jedlinská (Fig. 3) appears to have been exploiting the Weise Kluft vein (Fig. 2). However, we were unable to

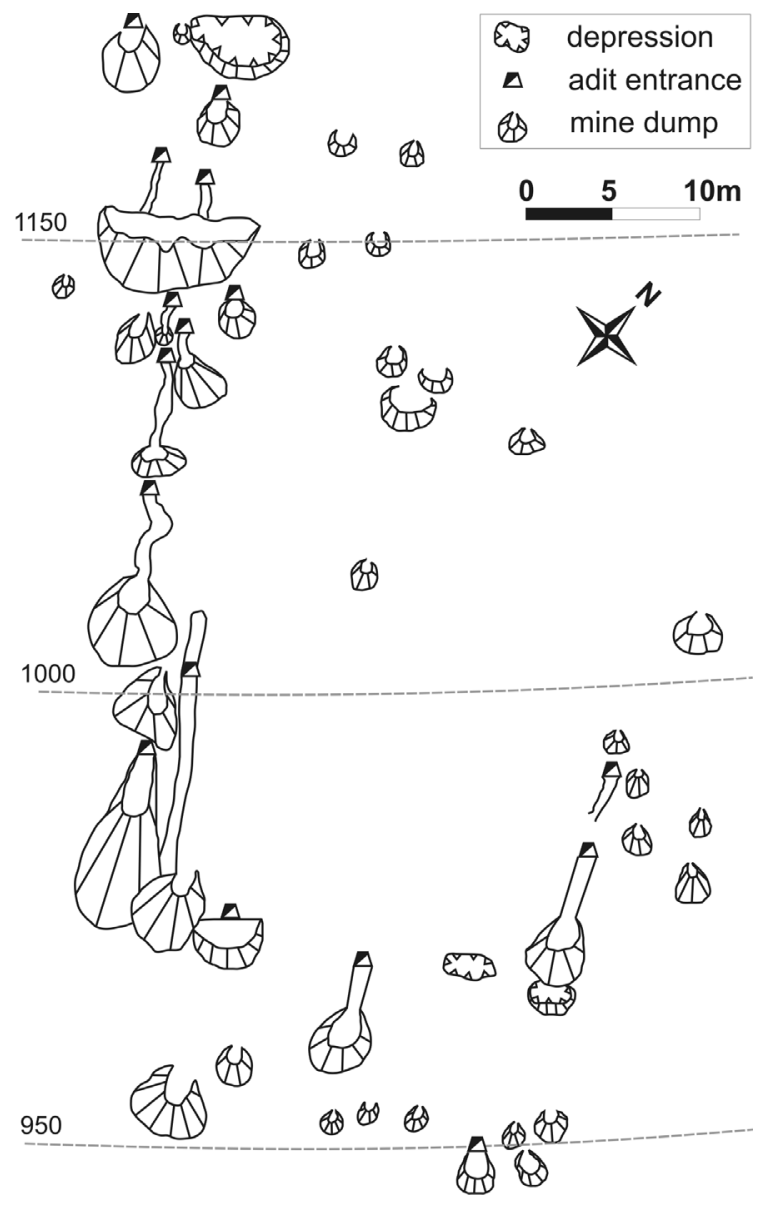

Fig. 3. Detailed location of old mining activities at Jedlinská 
determine the type of mineralization exploited because of the scarcity of ore samples. Regrettably, the only sulphides identified were arsenopyrite and pyrite disseminated in the altered granitic host rock.

\section{Primary minerals}

Arsenopyrite, one of the most abundant ore minerals in the deposit, is present in virtually all of the ore occurrences in the Nižná Boca area. Macroscopically, it forms clusters, nests and veinlets in quartz and hydrothermally-altered wallrock. Most crystals $(<3 \mathrm{~mm})$ are euhedral to subhedral, and with fractures that are cemented by other minerals, especially boulangerite, galena and gold (Fig. 4A, D, E; Fig. 7). The Au contents of monomineralic arsenopyrite crystals in five randomly selected ore samples, NB-Z24/25, NB-F2, NB-Z35/36, NB-Z4, NB-Z7, were 31.2, 10.7, 1166.7, 13.5, 5.4 and $25.3 \mathrm{ppm}$, respectively. The anomalously high Au content in sample NB-Z35/36 is likely due to the presence of particulate gold which commonly forms intimate intergrowths with arsenopyrite (Fig. 7). Older $\mathrm{Ti} \pm \mathrm{Fe}$ minerals are frequently enclosed as relics in arsenopyrite grains. Arsenopyrite is very closely associated with pyrite I. Their common grain contacts indicating equivocal relative ages combined with the lack of optical and chemical (BSE) zonality suggest that they were in equilibrium and at buffered $a S_{2}$ values at the time of deposition (Kretschmar, Scott 1976). The assumption of equilibrium along with the low ( $<1 \mathrm{wt} . \%)$ content of minor elements, e.g., Ni, Co and $\mathrm{Cu}$ (Table 1), the suitable Fe content (within $33.3 \pm 0.7$ at.\%) and an As content typical for arsenopyrite + pyrite parageneses $(<33.3$ at. $\%$ As) allows for the use of a thermometer determining the temperature of origin (Kretschmar, Scott 1976). After the chemical composition was determined by electron microprobe, a $\mathrm{d}_{131}$ value of 1.6325 , directly correlatable with the arsenopyrite As content, was obtained by XRD. The $d_{131}$ value was subsequently used to calculate the crystallization temperature of approximately $445^{\circ} \mathrm{C}$.

Barite occurs as a part of what is presumably the youngest mineral paragenesis together with hematite and pyrite (Fig. 4G). No luminescence in UV light was observed.

Carbonates are abundant in virtually all samples. All analysed carbonates are ferroan dolomite to ankerite (10.65-21.61 $\mathrm{mol}_{\%} \mathrm{FeCO}_{3}$; Fig. 5, Table 2) which frequently exhibits chemical zoning (Fig. 6). Concentric alternation of lighter and darker zones in BSE images likely reflects fluctuations in the Fe and Mn contents; lighter zones are typically enriched in Fe and/or Mn (Tablee 2). Carbonates are always younger than quartz and typically older than ore minerals within the same mineralization paragenesis. It is likely that several (up to three) generations of chemically similar carbonates associated with different ore mineral assemblages occur in the deposit. In some cases, a weak reddish luminescence was observed in the UV light.

Chalcopyrite is found only in a few samples. It occurs only as anhedral grains with older tetrahedrite in carbonate, rarely in quartz. It unclear; however, if it is a part of the $\mathrm{Sb}-\mathrm{Au}$ or siderite mineralization.

Galena is one of the most abundant ore minerals, commonly forming accumulations of high-luster silver-white grains up to few $\mathrm{mm}$ in size. Most of the galena from Nižná 

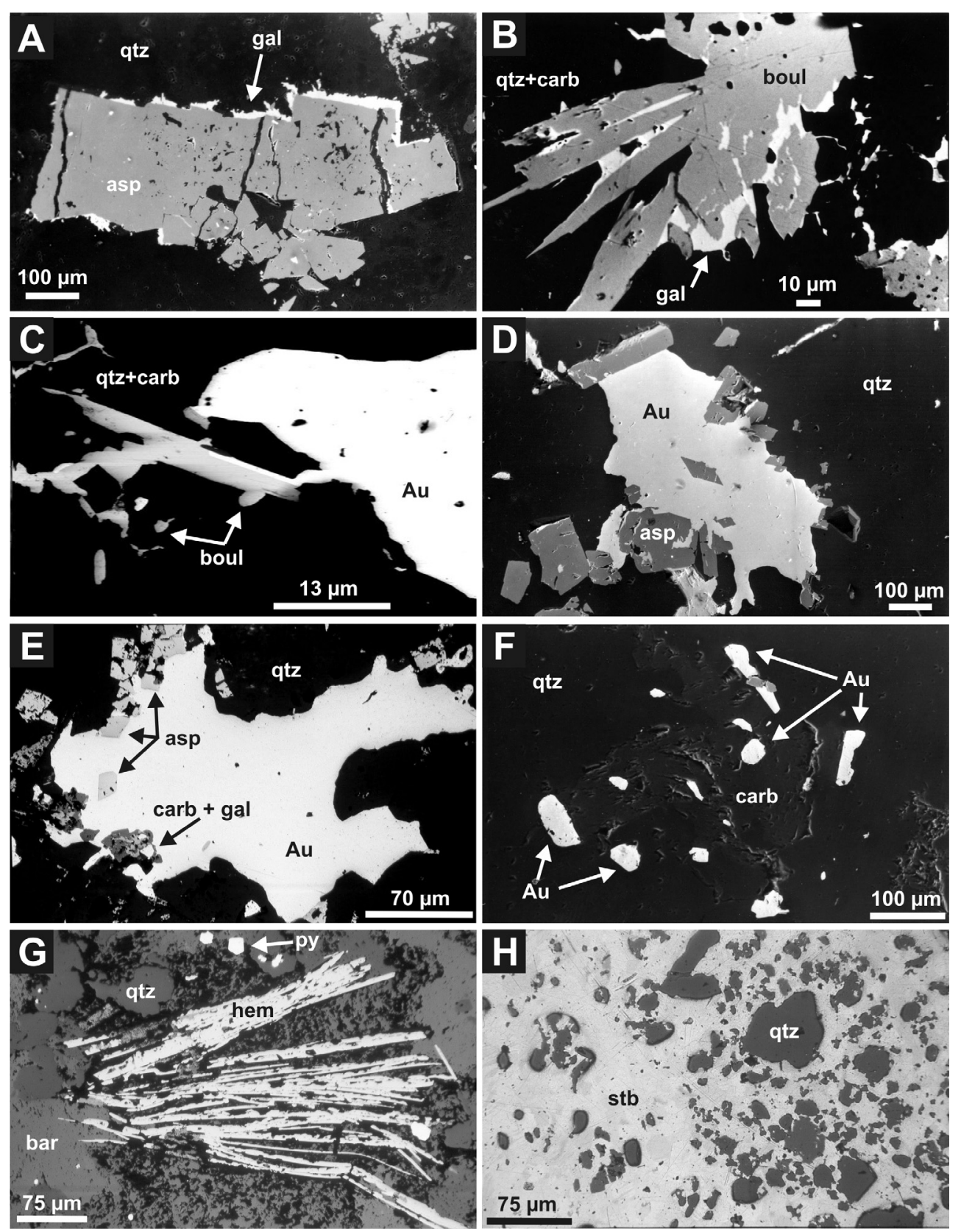

Fig. 4. BSE photographs of common ore mineral associations:

A - arsenopyrite (asp) replaced by younger galena, B - needle-shaped crystals of boulangerite (boul) replaced by younger galena, $\mathrm{C}$ - gold $(\mathrm{Au})$ replacing older boulangerite in a quartz (qtz) and carbonate (carb) matrix, D - gold replacing and enclosing older arsenopyrite grains, E - gold replacing and enclosing older arsenopyrite, carbonate and galena, $\mathrm{F}$ - anhedral gold grains dispersed in a carbonate matrix, G - hematite (hem) crystals with pyrite (py) in a quartz and barite (bar) matrix,

$\mathrm{H}$ - stibnite (stb) enclosing older anhedral quartz grains 


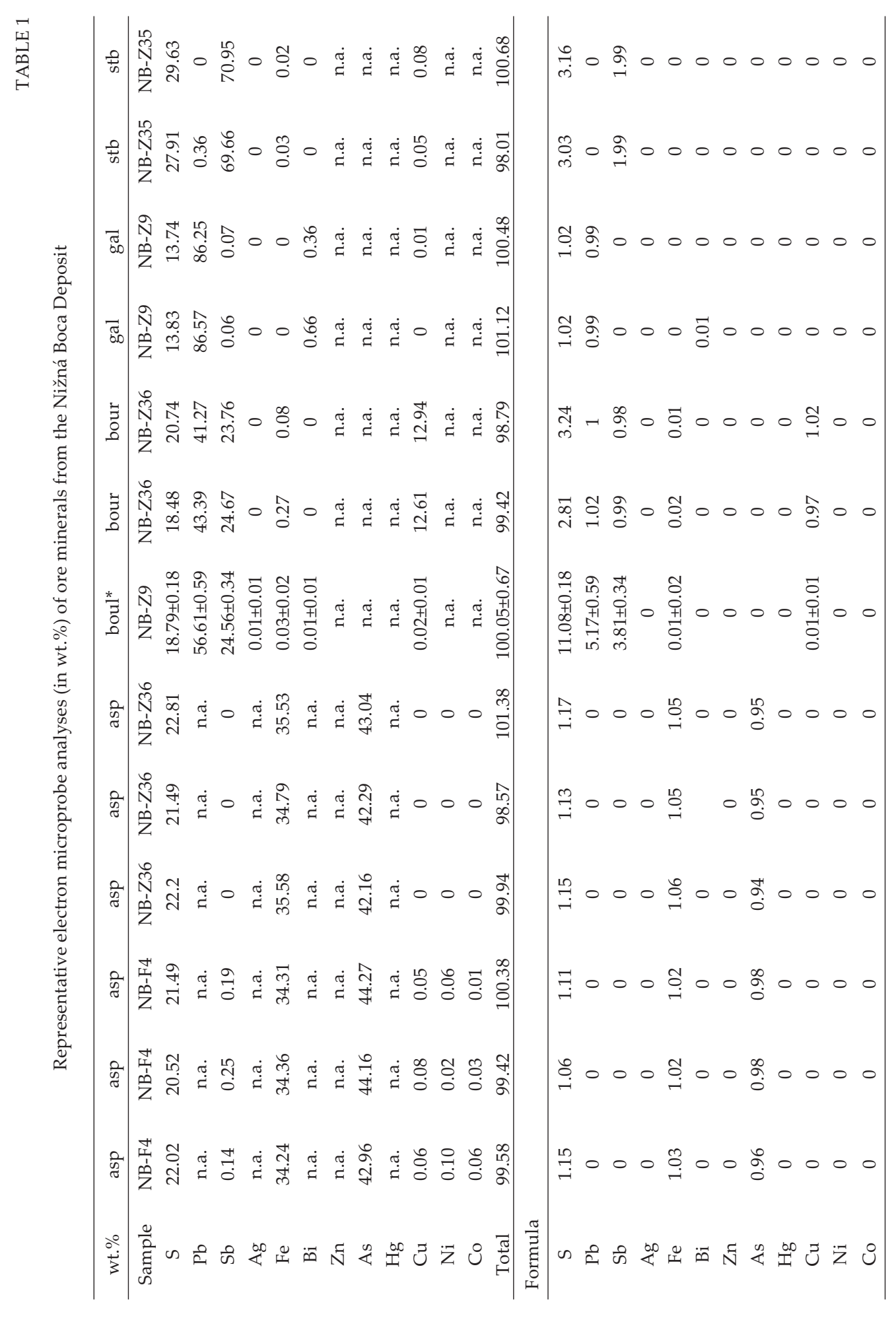




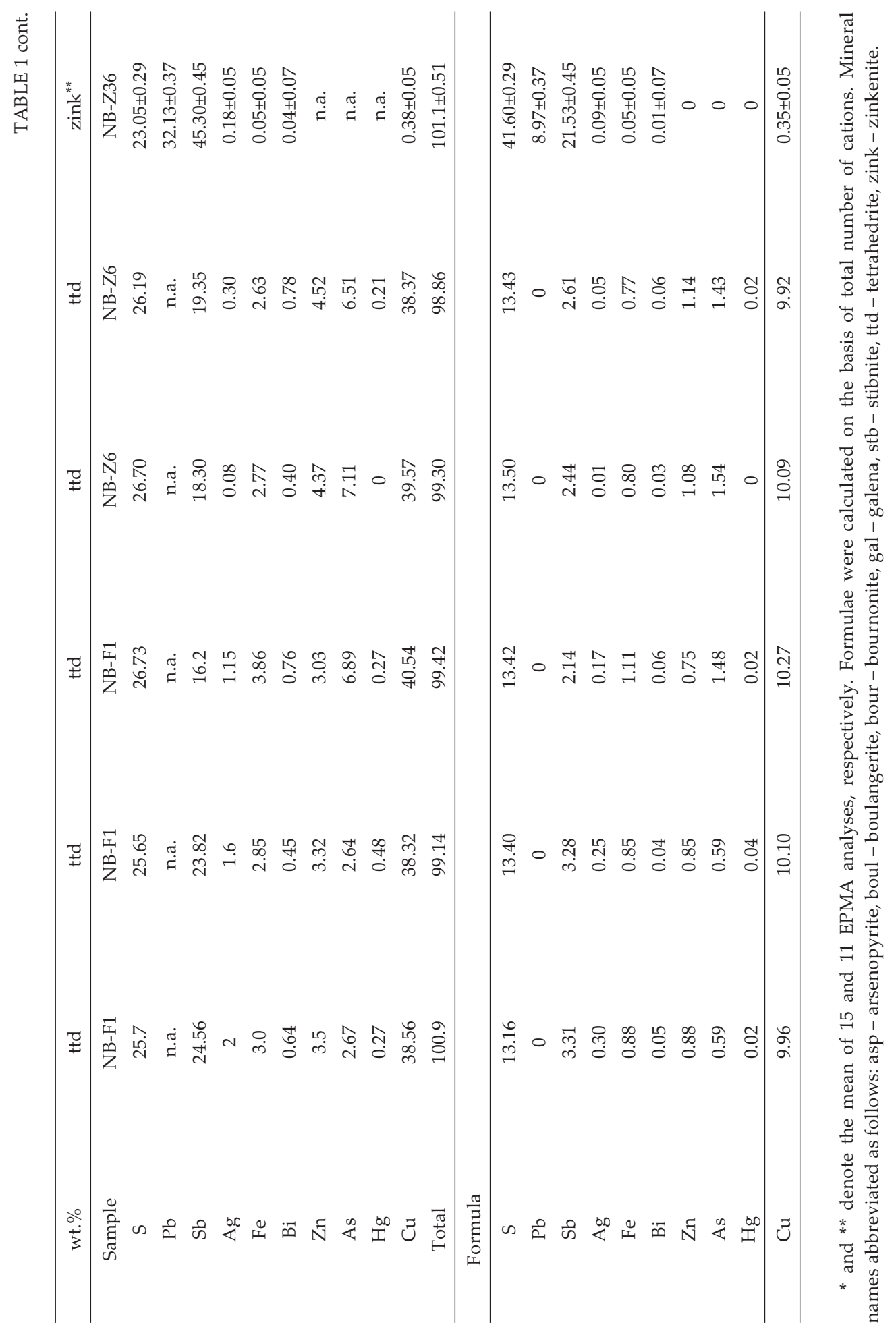



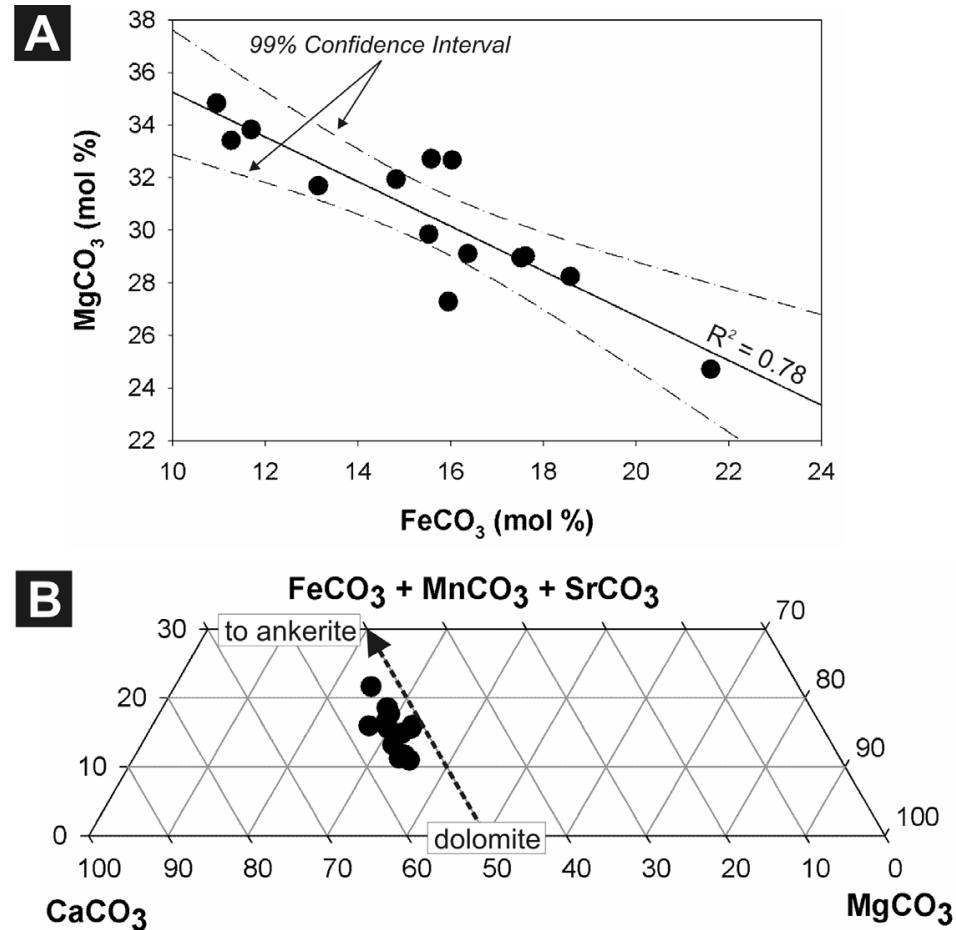

Fig. 5. Standardized EDS analyses of carbonates

$\mathrm{A}$ - correlation between Fe and $\mathrm{Mg}$ content of the carbonates, $\mathrm{B}$ - position of the Nižná Boca carbonates close to the dolomite $\left(\mathrm{MgCaCO}_{3}\right)$ - ankerite $\left(\mathrm{CaFeCO}_{3}\right)$ solid solution

TABLE 2

Chemical composition of carbonates (in mol \%) determined by standardized EDS analysis

\begin{tabular}{cccccccc}
\hline Sample & Place of analysis & $\mathrm{FeCO}_{3}$ & $\mathrm{MgCO}_{3}$ & $\mathrm{MnCO}_{3}$ & $\mathrm{CaCO}_{3}$ & $\mathrm{SrCO}_{3}$ & Total \\
\hline NB-Z35b & homogenous grain & 17.51 & 28.95 & 0.97 & 52.06 & 0.23 & 99.73 \\
NB-Z35b & homogenous grain & 17.61 & 29.02 & 0.79 & 51.28 & 0.46 & 99.15 \\
NB-Z35b & homogenous grain & 18.58 & 28.24 & 0.94 & 53.06 & 0 & 100.82 \\
NB-F3 & homogenous grain & 14.82 & 31.94 & 2.2 & 49.94 & 1.11 & 100.02 \\
NB-Z35e & light zone & 15.95 & 27.28 & 1.85 & 54.51 & n.a. & 99.58 \\
NB-Z35e & dark zone & 11.26 & 33.41 & 0.79 & 53.04 & n.a. & 98.5 \\
NB-Z35e & light zone & 16.37 & 29.1 & 0 & 53.38 & n.a. & 98.85 \\
NB-Z35e & dark zone & 13.14 & 31.69 & 0.83 & 53.17 & n.a. & 98.83 \\
NB-Z36k & dark zone & 11.69 & 33.83 & 0.49 & 53.79 & n.a. & 99.8 \\
NB-Z36k & light zone & 21.61 & 24.71 & 1.57 & 52.95 & n.a. & 100.84 \\
NB-Z36k & dark zone & 10.65 & 34.84 & 0.42 & 53.95 & n.a. & 100.16 \\
NB-Z36k & light zone & 15.53 & 29.85 & 0.5 & 53.1 & n.a. & 98.98 \\
\hline
\end{tabular}


Boca is anhedral and occurs in interstices, fissures and weakened cleavage zones in vein carbonates (Fig. 6) and quartz. As a younger mineral, galena very often replaces arsenopyrite, pyrite and sphalerite, penetrates along fissures and encloses entire grains of older minerals. Galena also commonly contains small anhedral inclusions of boulangerite and thus it appears that their crystallization periods overlapped and/or closely followed to each other. Galena only contains trace amounts of Bi (0.3-0.6 wt.\%; Table 1) and is optically and chemically homogenous.
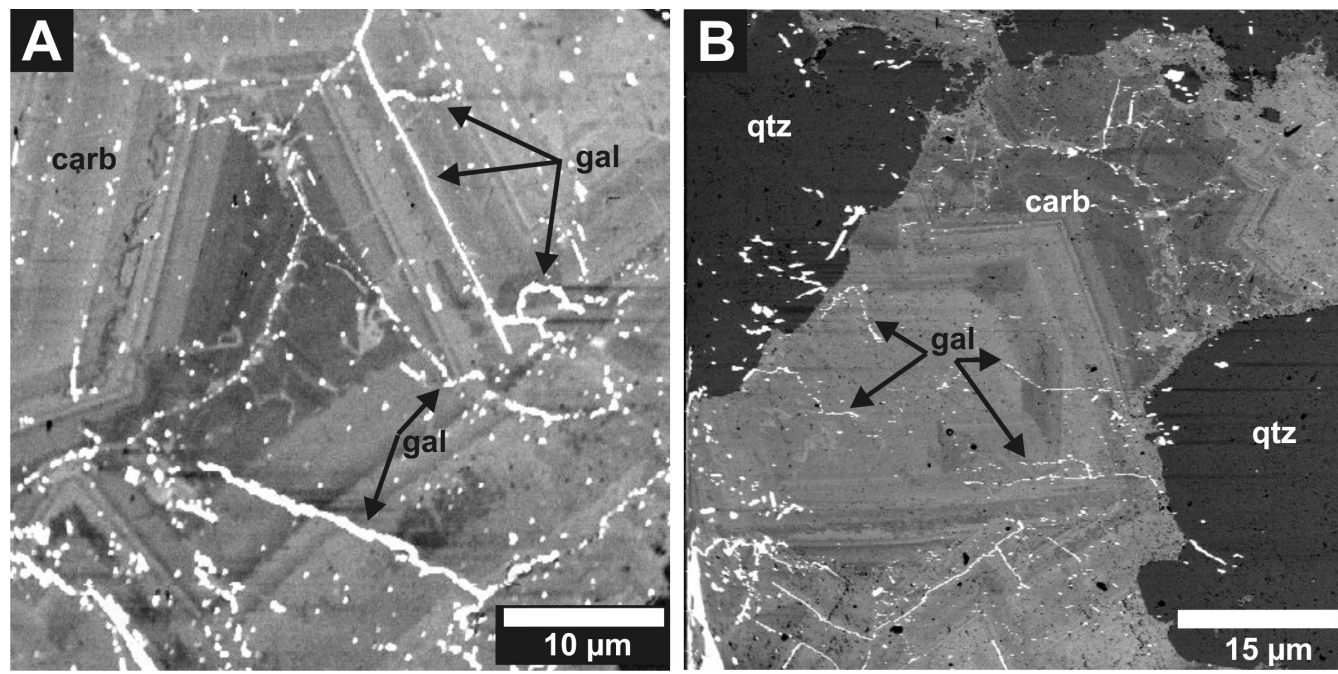

Fig. 6. BSE photographs of zoned ferroan dolomite (carb) with younger galena (gal) healing fractures (perpendicular to the growth zones) and weakened growth zones

Gold occurs scarcely but regularly in three microscopically distinct host settings:

1) replacing older sulphides, forming inclusions in arsenopyrite, pyrite, boulangerite and bournonite (Fig. 4C, E, D);

2) anhedral grains and veinlets in milky-white to smoky-grey quartz and, to a lesser extent, carbonate notably devoid of sulphides (Fig. 4F);

3) as arsenopyrite crystals filling microfractures (e.g., micro stringers $<1 \mu \mathrm{m}$ thick), possibly due to remobilization of "invisible" gold from the arsenopyrite structure (Fig. 7).

Analyses of gold from the Nižná Boca deposit show no differences in chemistry between the type 1 and type 2 gold (Fig. 8, Table 3). Type 3 gold was not analysed because its grain size proved prohibitively small for microprobe analysis. The size of gold grains varies from $0.002-2 \mathrm{~mm}$ with an average of $0.05 \mathrm{~mm}(\mathrm{n}=252)$. Its chemical composition is typically high in $\mathrm{Ag}$ (min. $13.37 \mathrm{wt} . \%$ ) and low concentrations of admixed elements $(<0.4 \mathrm{wt} . \%)$. True fineness $\left(F_{T}=[\mathrm{Au} / \mathrm{Au}+\mathrm{Ag}] \cdot 1000\right)$ values vary between 815-906. The Au and Ag contents of bulk ore samples are presented in Table 4.

Hematite is one of the youngest minerals in the deposit and is probably not related to the Sb-Au mineralization. Lamellae observed in reflected polarized light intersect is multiple grains and may indicate post-depositional stress. Hematite occurs in two 

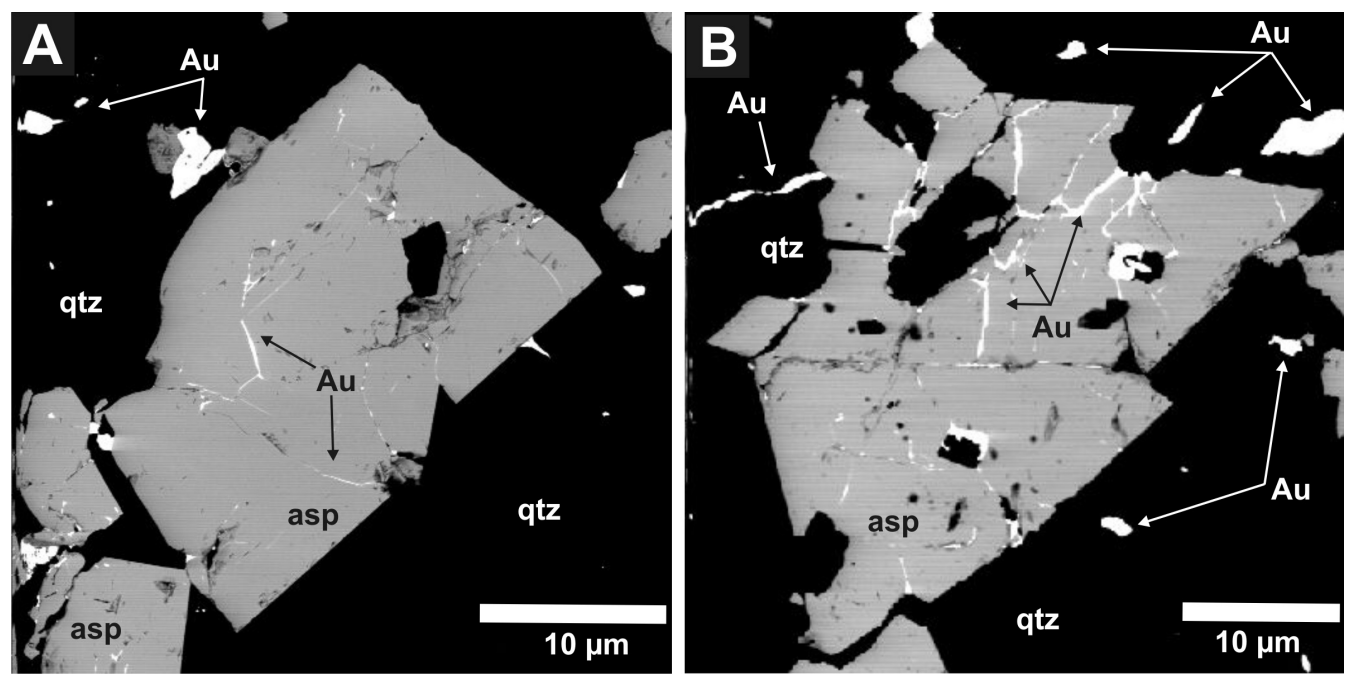

Fig. 7. BSE images of arsenopyrite crystals (asp) with micro-stringers of gold (Au). It is possible that two generations of gold are present (see text)

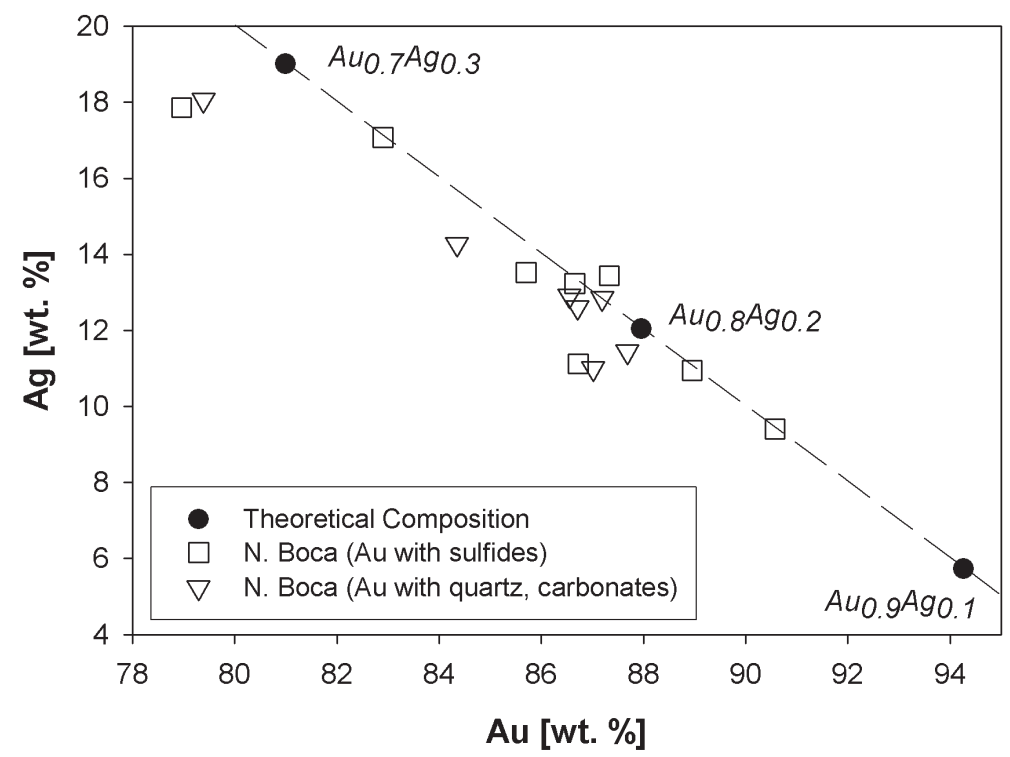

Fig. 8. Chemical composition of primary gold. Note the lack of systematic compositional variations in gold associated with quartz and carbonates versus sulphide minerals

distinct forms: 1) with barite as cement in older cataclased quartz and 2) anhedral to subhedral lath-like crystals in barite and carbonate, commonly in brush-like aggregates (Fig. 4G). Hematite often occurs together with pyrite; however, their relative age relationship is difficult to determine. 


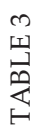

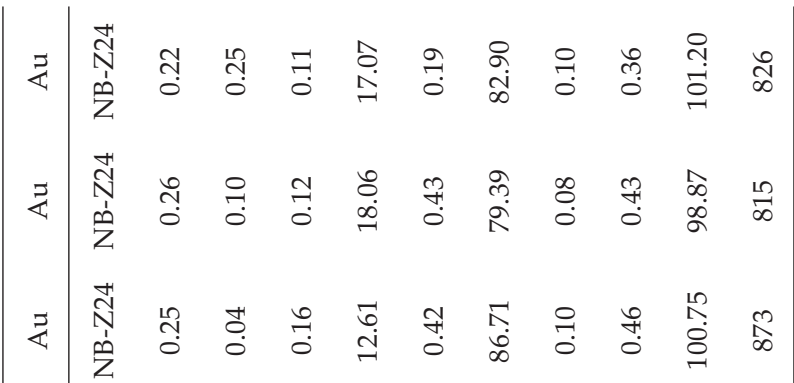

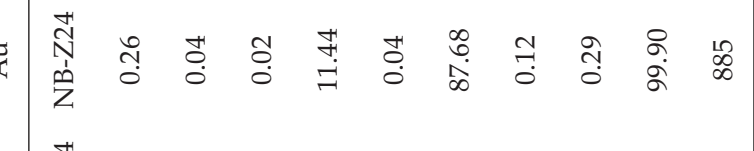

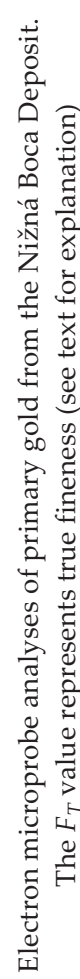

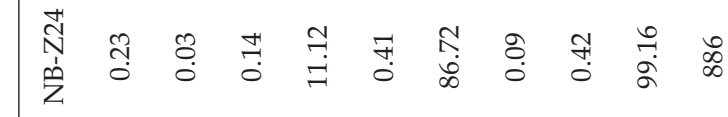

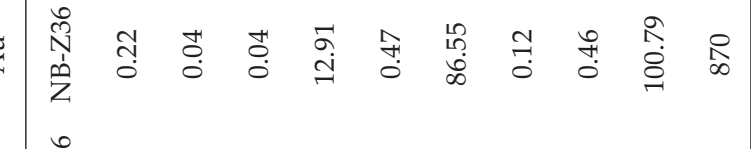

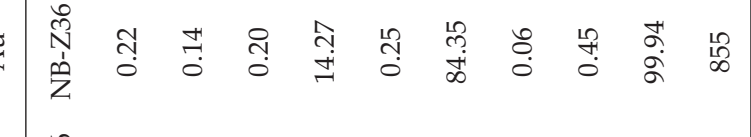

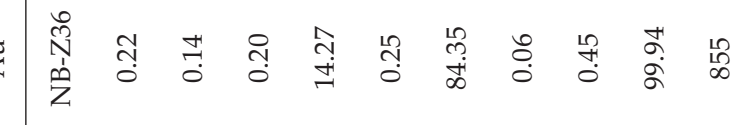

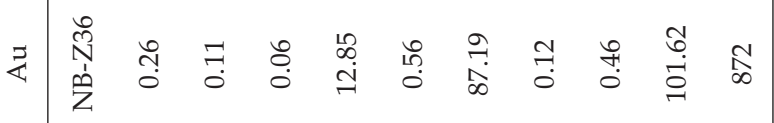

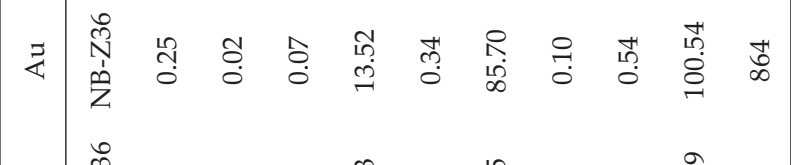

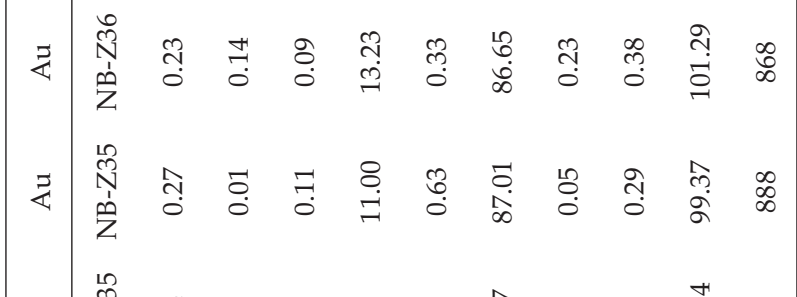

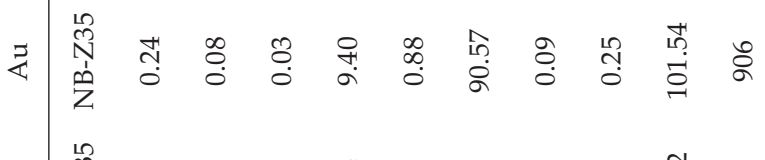

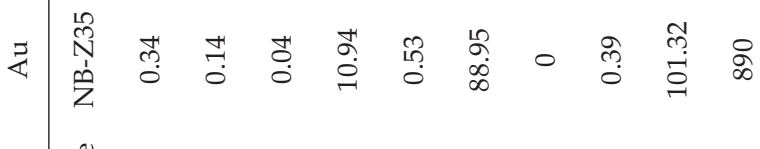

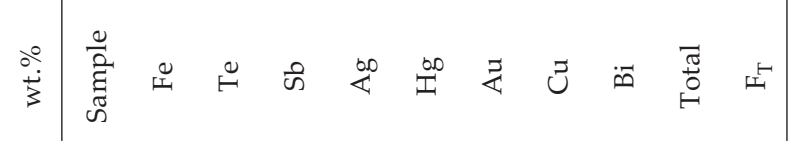


Gold and silver contents of bulk ore from various mineral parageneses determined by AAS

\begin{tabular}{cccc}
\hline Sample & Description & Au $\left(\mathrm{g} \cdot \mathrm{t}^{-1}\right)$ & $\mathrm{Ag}\left(\mathrm{g} \cdot \mathrm{t}^{-1}\right)$ \\
\hline NB-Z3 & $\begin{array}{c}\text { First mineral paragenesis with dominant quartz and } \\
\text { disseminated arsenopyrite and other sulphides }\end{array}$ & 1.91 & 0.9 \\
NB-Z35 & $\begin{array}{c}\text { Second mineral paragenesis with quartz, carbonate } \\
\text { and abundant coarse- to fine-grained stibnite }\end{array}$ & 3.95 & 24.8 \\
NB-Z50 & $\begin{array}{c}\text { Second mineral paragenesis with dominant quartz, carbonate } \\
\text { and disseminated needles and grains of ore minerals }\end{array}$ & 0.47 & 10.5 \\
NB-Z9 & $\begin{array}{c}\text { Third mineral paragenesis with smoky to milky white quartz } \\
\text { with frequent disseminated sulphides }\end{array}$ & 20.2 & 31.2 \\
NB-Z14 & Milky white quartz with rare disseminated sulphides & 0.53 & 21.1 \\
\hline
\end{tabular}

Marcasite is very rare, usually forming anhedral grains in quartz and in the wall-rock, and shows no specific relationship to other ore minerals.

$\mathrm{Pb}-\mathrm{Sb}-(\mathrm{Cu})-(\mathrm{Fe})$ sulphosalts occur commonly in two distinctive paragenetic settings depending on their $\mathrm{Pb} / \mathrm{Sb}$. For example, boulangerite and bournonite (high $\mathrm{Pb} / \mathrm{Sb}$ ) occur in the same paragenesis as galena, whereas zinkenite and berthierite (low $\mathrm{Pb} / \mathrm{Sb}$ ) are associated with stibnite (Fig. 9). The high $\mathrm{Pb} / \mathrm{Sb}$ paragenesis is younger than the low $\mathrm{Pb} / \mathrm{Sb}$ paragenesis (Fig. 10). Berthierite is rare, forming minute lath-like crystals enclosed in zinkenite and stibnite. Boulangerite, one of the most abundant sulphosalts in

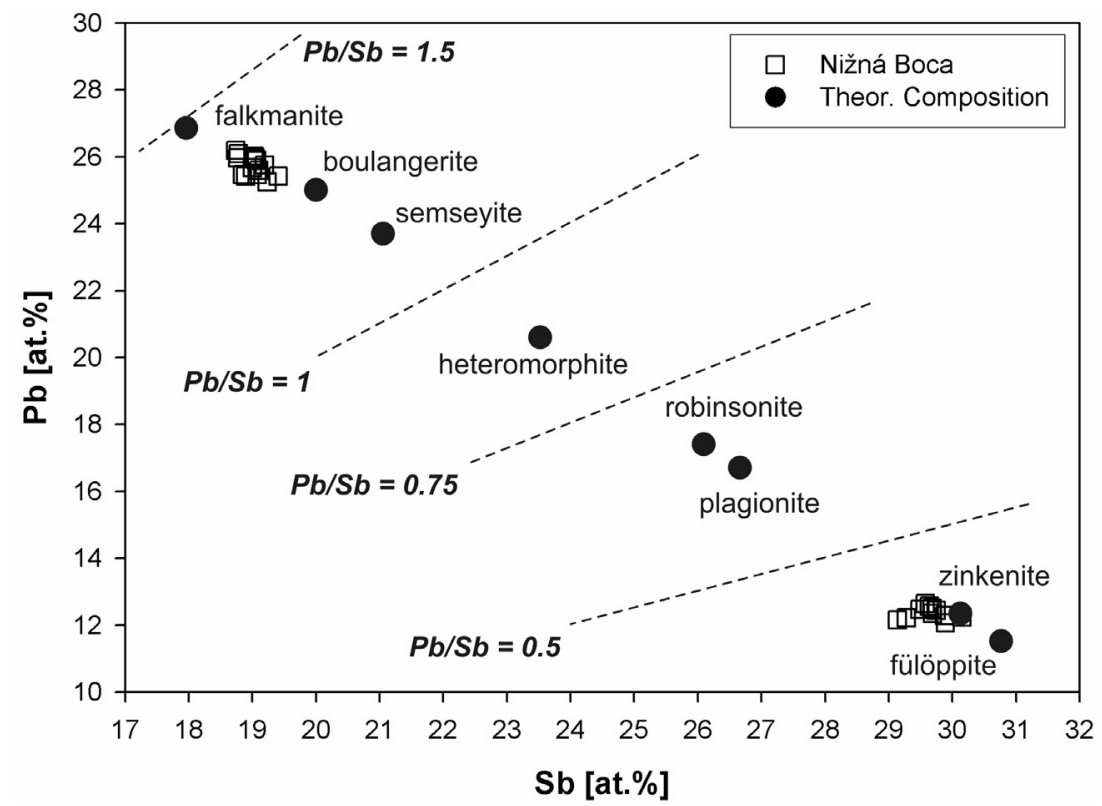

Fig. 9. Comparison of Pb-Sb sulphosalts from the Nižná Boca deposit to known theoretical compositions 

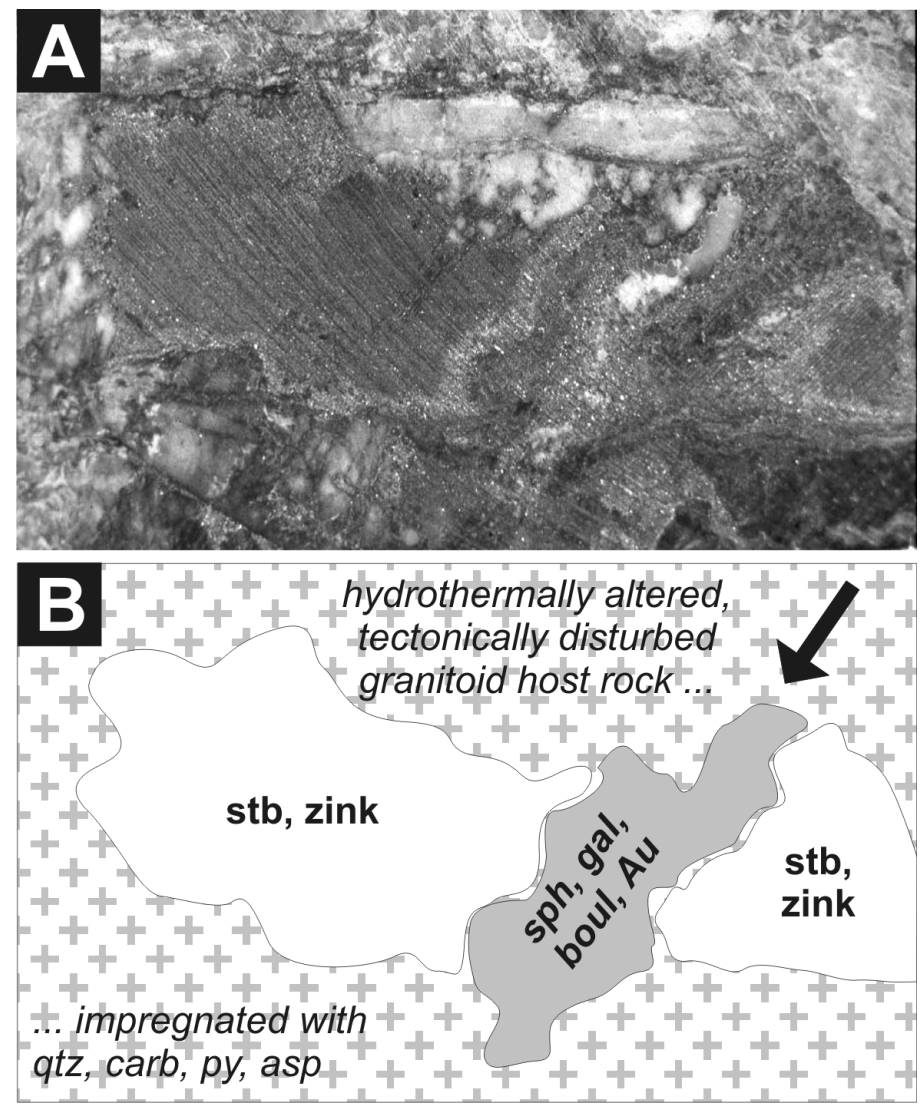

Fig. 10. Photograph (A) and a schematic sketch (B) of the $3^{\text {rd }}$ mineral paragenesis (stibnite, zinkenite-rich, low $\mathrm{Pb} / \mathrm{Sb}$ ) cutting a veinlet of the older $2^{\text {nd }}$ mineral paragenesis (galena, sphalerite, boulangerite-rich, high $\mathrm{Pb} / \mathrm{Sb}$ )

the deposit, occurs in smoky- to milky white quartz and in carbonates; it is usually associated with galena, sphalerite and gold. It usually forms small anhedral grains in galena, quartz and carbonates or needle-like crystals in quartz and carbonates (Fig. 4B, C) and commonly fills carbonate cleavage planes or fissures penetrating several host-mineral grains. Boulangerite often replaces older minerals, mainly arsenopyrite, pyrite and sphalerite. Its formula based on 15 analyses (Table 1) is $\mathrm{Pb}_{5.17} \mathrm{Sb}_{3.81} \mathrm{~S}_{11.08}$. Bournonite is rare and always in the form of small anhedral grains in quartz, carbonates and, in occasional instances, boulangerite. Analyses of bournonite are given in Table 1 and its formula based on three analyses is near stoichiometric $\mathrm{Cu}_{0.99} \mathrm{~Pb}_{1.00} \mathrm{Sb}_{0.99} \mathrm{~S}_{3.01}$. Zinkenite is abundant, forming veins and aggregates in quartz, carbonates and, rarely, in the hydrothermally altered wall-rock. Its anhedral or euhedral needle-like crystals also commonly associate with stibnite (age relationship unclear) or replace older sulphides, especially pyrite and arsenopyrite. The average formula, based on 11 microprobe analyses, was calculated to be $\mathrm{Cu}_{0.35} \mathrm{Ag}_{0.09} \mathrm{~Pb}_{8.97} \mathrm{Fe}_{0.05} \mathrm{Sb}_{21.53} \mathrm{Bi}_{0.01} \mathrm{~S}_{41.60}$ (Table 1). $\mathrm{Cu}$ likely enters the structure by the "aikinite" type of substitution $\mathrm{Cu}+\mathrm{Pb} \rightarrow \mathrm{Sb}+\square$, 
Fe by the simple $\mathrm{Fe} \rightarrow \mathrm{Pb}$ substitution and Ag by the "lillianite" type of substitution $\mathrm{Ag}+\mathrm{Sb} \rightarrow 2 \mathrm{~Pb}$ (Makovický 1989). Taking into account these substitutions, the simplified formula could be written as $\mathrm{Pb}_{8.85} \mathrm{Sb}_{21.80} \mathrm{~S}_{41.60}$.

Pyrite, as anhedral to euhedral crystals $<3 \mathrm{~mm}$ in size, is one of the most abundant minerals in the Nižná Boca area. It occurs both in hydrothermal veins and in wall-rock alteration zones, and is commonly weathered to secondary Fe minerals such as goethite or jarosite. Based on microscopic observation, three generations of pyrite in different mineral parageneses can be recognised. Pyrite I (oldest) is associated with arsenopyrite in quartz veins and wall-rock alteration zones, often forming banded textures. It usually forms chemically- and optically homogenous subhedral to euhedral crystals that are commonly cataclased and cemented by younger minerals (e.g., Pb-Sb sulphosalts, galena, gold). Inclusions of Ti-minerals (rutile, ilmenite) are sporadic. Pyrite II is associated with sphalerite, galena, boulangerite, bournonite and gold, often filling fractures in quartz and carbonate. It usually forms subhedral to euhedral homogenous crystals. Pyrite III (the youngest), associated with hematite and barite, often forms euhedral crystals (Fig. 4G).

Pyrrhotite is very rare as anhedral grains in wall-rock alteration zones and in the host rock. Relationships to other ore minerals are unclear.

Quartz, the dominant gangue mineral, occurs in several generations distinguished on the basis of textural and structural observations. Quartz I is usually coarse-grained and associated with arsenopyrite and pyrite I. Its colour is sometimes influenced by finely dispersed sulphides and by coatings of secondary Fe-minerals. It is often intensely fractured and replaced by younger mineral parageneses, including quartz. As the most reliably identifiable, Quartz I was chosen for fluid inclusion studies (see below). Quartz II is milky-white and associates with younger ferroan dolomite, stibnite and zinkenite. Quartz III usually occurs closely intergrown with younger ferroan dolomite, pyrite II, sphalerite, galena, boulangerite and gold (Fig. 4C, F).

Sphalerite commonly forms aggregates of brown red anhedral grains in quartz and carbonate vein fillings. It is often associated with, and replaced by, younger minerals, especially boulangerite, galena and gold.

Stibnite is rare. It forms veins $(<4 \mathrm{~cm})$ and aggregates with minor coarse-grained milky-white quartz and rare carbonate in the hydrothermally-altered host tonalite. Microscopically, needle-like crystals are scarce; the dominant anhedral grains often cement brecciated quartz grains, fill cracks and cavities, and replace older arsenopyrite and pyrite (Fig. $4 \mathrm{H}$ ). Deformation lamellae are common but any indication of recrystallization (e.g., fine-grained veinlets) is lacking. An analysis is given in Table 1.

Tetrahedrite is very rare. It is seen only microscopically as anhedral grains in quartz and carbonates with younger chalcopyrite. Sporadically, it replaces pyrite, galena and boulangerite. Tetrahedrite from both the siderite mineralization (Fišiarka - sample NB-F1) and the Sb-Au mineralization (Zach - NB-Z6) is included in Table 1. Even though limited As-Sb substitution (up to $7.1 \mathrm{wt} . \% \mathrm{As}$ ) and a low Ag content ( $<2 \mathrm{wt} . \%$ ) characterizes tetrahedrite from both samples, their accessory nature inhibited further analysis and comment on their chemical differences. The average formula based on 5 EPMA analyzes can be written as $\mathrm{Cu}_{10.07} \mathrm{Ag}_{0.16} \mathrm{Zn}_{0.94} \mathrm{Fe}_{0.89} \mathrm{Sb}_{2.75} \mathrm{As}_{1.12} \mathrm{Bi}_{0.05} \mathrm{~S}_{13.38}$. 
Ti-minerals (rutile, ilmenite) occur commonly, predominantly as anhedral, deformed grains in the oldest sulphides (arsenopyrite, pyrite I), quartz, carbonates, wall-rock and the host rock.

\section{Secondary minerals}

Secondary Fe minerals in the deposit are represented by goethite, jarosite, rosenite and possibly other phases lacking long-range structural order detectable by XRD. They usually occur together in a mixture of brownish to yellowish colour which forms coatings and accumulations (nests) of various thickness and size on primary Fe-bearing minerals, typically pyrite and carbonates.

Secondary $\mathrm{Sb}$ minerals are represented only by stibiconite (detected by XRD), which forms pale- to dark yellow powder accumulations on weathered stibnite and $\mathrm{Pb}-\mathrm{Sb}$ sulphosalts.

\section{Fluid inclusions}

Fluid inclusions irregularly disseminated in quartz from the first mineral paragenesis (quartz - arsenopyrite, pyrite) were studied by optical microthermometry. The quartz matrix from subsequent parageneses and carbonates were not suitable for fluid inclusion study because of complicated genetic relationships, fine mutual intergrowths and/or small inclusion sizes. Only primary inclusions were studied though, in some cases, their designation as primary (sensu Roedder 1984) was ambiguous. The inclusions are predominantly irregular in shape with sizes ranging from $<2-17 \mu \mathrm{m}$ with an

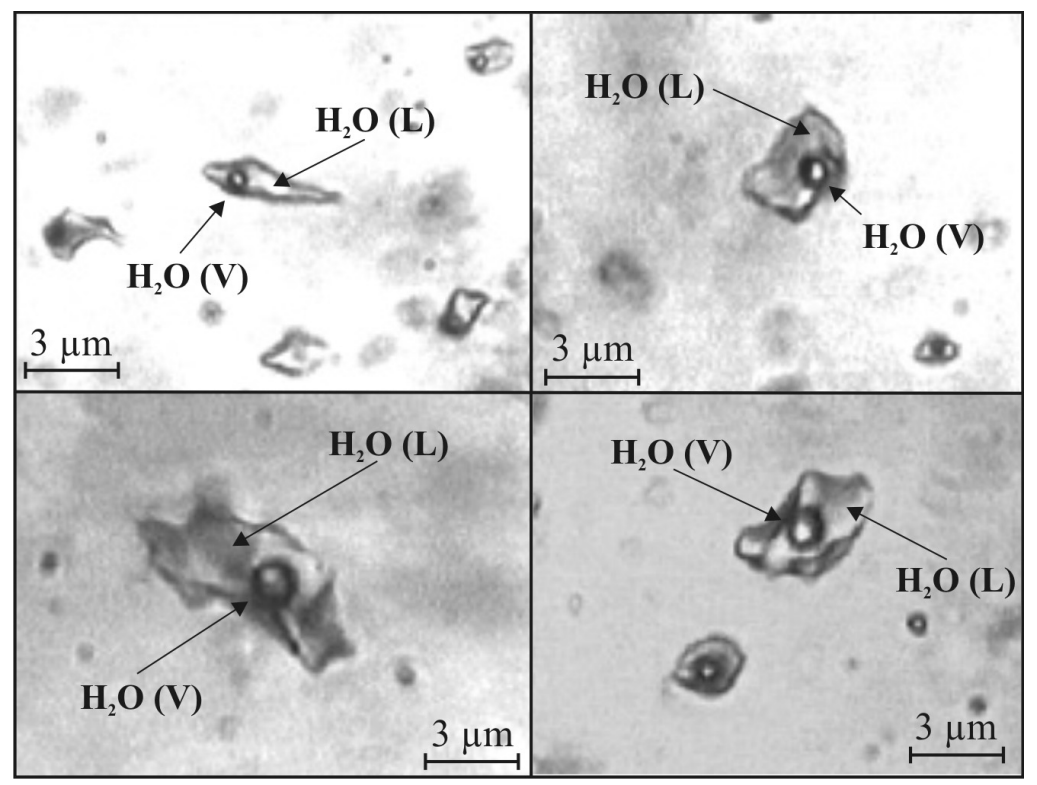

Fig. 11. Two-phase $(\mathrm{L}+\mathrm{V})$ fluid inclusions in quartz I of the first mineral paragenesis (Stage I) 
average of $4.5 \mu \mathrm{m}(\mathrm{n}=51)$. All inclusions examined are two-phase (liquid + gas) with the liquid phase predominant (Fig. 11). Melting of totally frozen inclusions was observed to start between -23.9 and $-21.2^{\circ} \mathrm{C}$. Owing to their small size, the eutectic temperature $(\mathrm{Te})$ was not measured in all inclusions. The Te values relate to the $\mathrm{H}_{2} \mathrm{O}-\mathrm{NaCl}-(\mathrm{KCl}$ ?) system (Borisenko, 1977 in Shepherd et al. 1985). Double freezing of aqueous liquid indicative of the presence of $\mathrm{CO}_{2}$ was not observed. Therefore, the $\mathrm{CO}_{2}$ concentrations were $<3.6 \mathrm{wt}$. $\%$. Temperatures of ice melting $\left(T m_{i c e}=-1.6\right.$ to $\left.-12.4^{\circ} \mathrm{C}\right)$ correspond to salinities between $2.7-16.3$ wt.\% $\mathrm{NaCl}_{\mathrm{eq}}$ (Fig. 12A; Hall et al. 1988). Occasionally, metastable
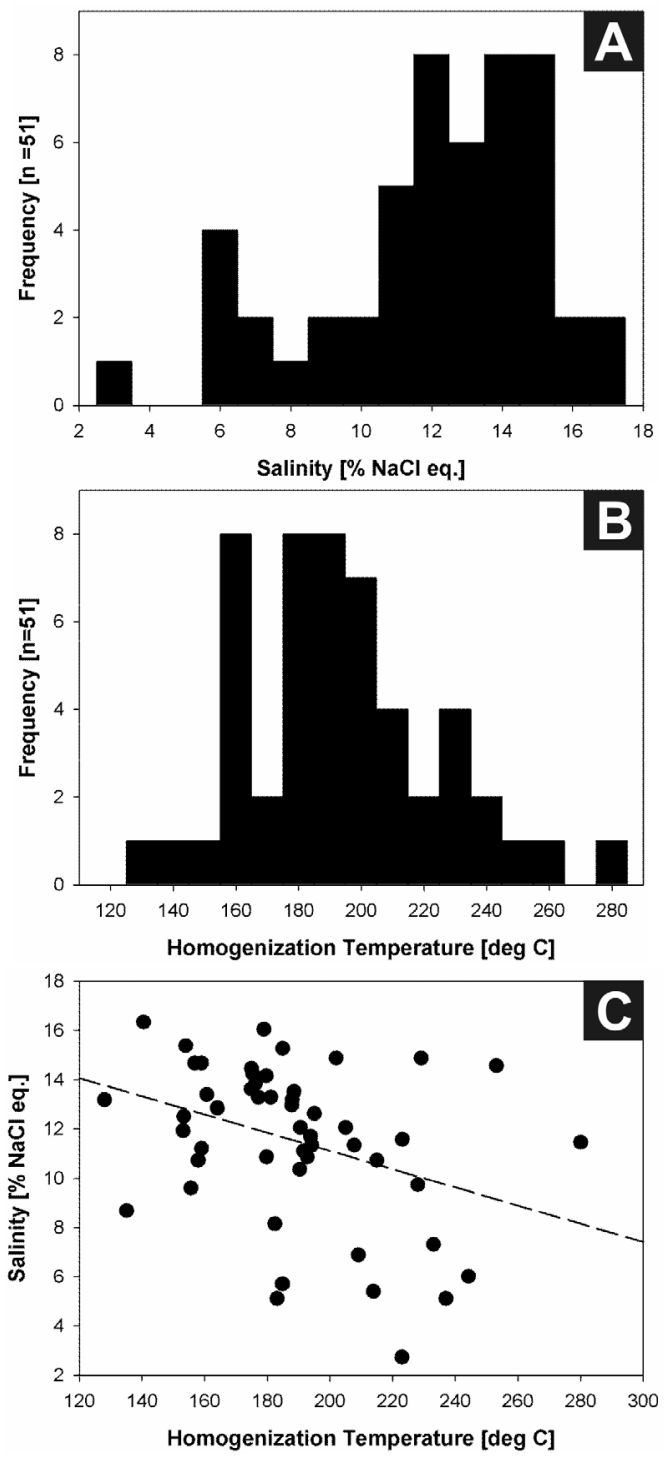

Fig. 12. Calculated salinities (A); homogenization temperatures $(B)$ and $(C)$ correlation $\left(R^{2}=-0.36\right)$ between homogenization temperature and salinity in fluid inclusions $(n=51)$ from quartz I (stage I) 
superheated ice melted at temperatures as high as $+8.4^{\circ} \mathrm{C}$ in inclusions with extremely small vapor bubbles. All inclusions homogenized to liquid at temperatures between $128-280^{\circ} \mathrm{C}$ (Fig. 12B) corresponding to liquid densities between $1.03-0.85 \mathrm{~g} . \mathrm{cm}^{-1}$, by reference to a $\mathrm{H}_{2} \mathrm{O}-\mathrm{NaCl}$ system (Hurai 1988). Poor correlation $\left(\mathrm{R}^{2}=-0.36\right.$ ) between the homogenization temperature and salinity does not permit a distinction between fluid boiling and mixing, i.e., two possible mechanisms which could account for the wide range of observed salinities (Fig. 12C).

\section{PARAGENETIC CONSIDERATIONS AND DISCUSSION}

Based on our macroscopic and microscopic observations, we propose a model with 5 main stages of mineralization for the Nižná Boca deposit. It is important to note that all samples on which the model is based were collected ex-situ from mine dumps and, therefore, it cannot be considered complete and unequivocally correct. The model comprises the following depositional sequence (ordered from oldest to youngest relative age of minerals):

I. Quartz I - arsenopyrite, pyrite I, marcasite(?), pyrhotite(?) - gold(?).

II. Quartz II - ferroan dolomite/ankerite - stibnite, zinkenite, berthierite.

III. Quartz III - ferroan dolomite/ankerite - pyrite II - sphalerite - galena, boulangerite, bournonite - gold.

IV. Quartz(?) - carbonate(?) - tetrahedrite - chalcopyrite.

V. Barite - hematite, pyrite.

The first mineral paragenesis (oldest) is usually disseminated in the hydrothermally altered granitic host rock although discrete veinlets also occur. Brittle deformation of the $1^{\text {st }}$ stage is documented by arsenopyrite and pyrite I cataclasis followed by the healing of fractures by other minerals, most commonly gold and boulangerite. It is possible that native gold also formed during this stage; however, due to the lack of distinctive chemistry we are unable to differentiate it from gold in younger mineralization stages (Fig. 8). The most common basis for such distinction is the Ag content of gold as has been shown in other deposits in the Nízke Tatry Mountains (e.g., Chovan et al. 1995b; Bakos, Chovan 1999) and elsewhere (e.g., Dill et al. 1995; Mikuš, Chovan 2003). In other deposits, however, such a systematic variation in Ag content may be missing entirely (e.g., Majzlan, Chovan 1997; Oberthür et al. 1997; Uemoto et al. 2002; Helmy et al. 2004). Because arsenopyrite from Nižná Boca is gold-bearing, we hypothesize that it may have served, to some extent, as the source of the native gold remobilized during high temperature/pressure events. This remobilized gold was deposited as minute $(<1 \mu \mathrm{m})$ stringers in arsenopyrite crystals or in their close vicinity (Fig. 7). Such a mechanism has been proposed for some deposits in southern India (Saha, Venkatesh 2002), Canada (Larocque et al. 1995), Ghana (Mumin et al. 1994; Helmy et al. 2004), Western Australia (Vaughan, Kyin 2004), Bolivia (Dill et al. 1995) and the Balkans (Mladenova et al. 2004). Further useful comment awaits appropriate chemical analyses.

The second, stibnite-bearing (high $\mathrm{Sb}$ ) paragenesis forms veins $<4 \mathrm{~cm}$ thick and comprises coarse-grained milky-white quartz II, ferroan dolomite, stibnite, zinkenite 
and berthierite. The stibnite is fine- to coarse grained without any recrystallization features. Though zinkenite was the only $\mathrm{Pb}-\mathrm{Sb}$ sulphosalt found in this paragenesis, it is possible that other sulphosalts with high $\mathrm{Sb} / \mathrm{Pb}$, e.g., füllöppite, plagionite, occur (Fig. 9).

The third (high $\mathrm{Pb}$ ) paragenesis is the most abundant in the deposit. Milky-white to smoky-grey quartz III and ferroan dolomite host pyrite II, sphalerite, galena, boulangerite, bournonite and gold. Other sulphosalts with high $\mathrm{Pb} / \mathrm{Sb}$, e.g., semseyite, may be also present in this paragenesis. Analyses of the boulangerite (Table 1) show a higher $\mathrm{Pb}$ content than its ideal composition $\left(\mathrm{Pb}_{5} \mathrm{Sb}_{4} \mathrm{~S}_{11}\right)$ and, thus, it plots between boulangerite and falkmanite $\left(\mathrm{Pb}_{5.4} \mathrm{Sb}_{3.6} \mathrm{~S}_{11}\right)$ on the $\mathrm{Pb}$ vs. Sb chart (Fig. 9). Because they are members of the same boulangerite homologous series $\left(\mathrm{Me}_{9} \mathrm{~S}_{11}\right)$ (Mozgova et al. 1983) and have very similar chemical compositions, their XRD powder diffraction patterns exhibit only negligible differences. A single crystal XRD analysis is therefore required for definite identification. Interestingly, boulangerite non-stoichiometry is a commonly observed phenomenon in Sb-Au deposits across the Ďumbierske Nízke Tatry Mountains (Pršek pers. comm).

In one macroscopic sample, an ore veinlet $(\sim 2 \mathrm{~cm}$ thick) of this paragenesis was observed to intersect a veinlet of the older, second stibnite-bearing paragenesis unequivocally establishing their relative ages. The mutual age relationship of the Sband $\mathrm{Pb}$-rich parageneses in Nižná Boca is similar to that in deposits at Magurka (Chovan et al. 1995b), Klačianka, Krámec and Vel'ké Oružné (Bakos et al. 2000), Malé Železné (Pršek - pers. comm.), but the reverse of that in the Dúbrava Deposit (Chovan 1990).

The fourth mineral paragenesis occurs sparsely - replacing boulangerite from the previous mineral paragenesis. The fifth paragenesis with barite, hematite and pyrite is probably not genetically linked to the Sb-Au hydrothermal mineralization but is of younger relative age (Chovan et al. 1996; Bakos et al. 2000).

\section{CONCLUSIONS}

In spite of abundant records of Boca gold mining in the archives (e.g., Central Mining Archive in Banská Štiavnica, Slovakia), detailed field reconnaissance and mineralogical research has not been conducted there since the decline of gold mining in the late $19^{\text {th }}$ century. Presumably due to its small size and lesser economic importance, it was not even included in the comprehensive work on stibnite deposits in the Nízke Tatry Mountains by Hak (1966). Based on our field research, we have confirmed occurrences of $\mathrm{Sb}$-Au mineralization over an area of about $2 \mathrm{~km}^{2}$ in the mine field Zach (Fig. 2) in workings striking N-S to NW-SE. Several new occurrences of siderite mineralization (sensu Chovan et al. 1996) were also discovered. The Sb-Au mineralization is hosted by biotite tonalities to granodiorites of the Dumbier Type which is in agreement with the archive data (e.g., Slavkay 1988) and the geological map of the Nízke Tatry Mountains (Biely 1992). The results presented here expand our knowledge of the deposit, most notably its mineralogy and depositional sequence, and contribute to our understanding of metallogenesis in the Nízke Tatry Mountains. 
Acknowledgements. The authors would like to thank Marcela Herichová, the mayor of the Nižná Boca village, for support and the Mazanec family for graciously providing us with a base camp for the field-work. The help of Veronika Szabadová (Comenius University) with the preparation of polished sections is greatly appreciated. Dr. Peter Andráš (Slovak Academy of Sciences) is thanked for OES analyses of gold in arsenopyrites. Drs Monika Huraiová, Vratislav Hurai (Comenius University) and Peter Kodera (Geol. Survey of Slovak Rep.) are thanked for their help with the fluid-inclusion research. This work was supported by VEGA grants No.1/8318/01 and No.1/4048/07 awarded to Martin Chovan.

\section{REFERENCES}

BAKOS F., CHOVAN M., 1999: The genetic types of gold at the Magurka Deposit. Mineralia Slovaca 31, 3-4, 217-225 (in Slovak).

BAKOS F., CHOVAN M., MICHÁLEK J., 2000: Mineralogy of hydrothermal Sb, Cu, Pb, Zn, As mineralization in NE of the Magurka deposit, Nízke Tatry Mts. Mineralia Slovaca 32, 497-506 (in Slovak).

BERGFEST A., 1952: Mining in Boca. The Central Mining Archive Banská Štiavnica, 76 pp. (in Slovak).

BIELY A. (Ed.), 1992: The geologic map of the Nízke Tatry Mountains. Bratislava, Geologic Institute of Dionýz Štúr (in Slovak).

BROSKA I., UHER P., 2001: Whole-rock chemistry and genetic typology of the West-Carpathian Variscan granites. Geologica Carpathica 52, 2, 79-90.

CAMBEL B., KRÁL' J., BURCHART J., 1990: Isotope geochronology of the Western Carpathian Basement. Bratislava, VEDA, 183 pp. (in Slovak).

CHOVAN M., 1990: Mineralogical-paragenetical relations at the Dúbrava Sb Deposit and their significance for metallogenesis of the Nízke Tatry Mts. Acta Geologica et Geographica Universitatis Comenianae 15, 89-101.

CHOVAN M., HURAI V., SACHAN H.K., KANTOR J., 1995a: Origin of the fluids associated with granodiorite-hosted, Sb-As-Au-W mineralization at Dúbrava (Nízke-Tatry Mts, Western Carpathians). Mineralium Deposita 30, 1, 48-54.

CHOVAN M., PÓČ I., JANCSY P., MAJZLAN J., KRIŠTÍN J., 1995b: Ore Sb-Au-(As-Pb) mineralization in the Magurka Sb-Au Deposit, The Nízke Tatry Mountains. Mineralia Slovaca 27, 6, 349-406 (in Slovak).

CHOVAN M., SLAVKAY M., MICHÁLEK J., 1996: Ore mineralizations of the Ďumbierske Tatry Mts (Western Carpathians, Slovakia). Geologica Carpathica 47, 6, 371-382.

CHOVAN M., MAJZLAN J., RAGAN M., SIMAN P., KRIŠTÍN J., 1998: Pb-Sb and Pb-Sb-Bi sulfosalts and associated sulphides from Dúbrava antimony deposit, Nízke Tatry Mts. Acta Geologica Universitatis Comenianae 53, 37-49.

DILL H.G., WEISER T., BERNHARDT I.R., KILIBARDA C.R., 1995: The composite gold-antimony vein deposit at Kharma (Bolivia). Economic Geology 90, 1, 51-66.

DOSTAL J., VOZÁR J., KEPPIE J.D., HOVORKA D., 2003: Permian volcanism in the Central Western Carpathians (Slovakia): Basin-and-Range type rifting in the southern Laurussian margin. International Journal of Earth Sciences 92, 1, 27-35.

HAK J. ,1966: Mineralogy and geochemistry of stibnite deposits in the Nízke Tatry Mts. Sborník Geologických Věd 7, 71-144 (in Czech).

HALL D.L., STERNER S.M., BODNAR R.J., 1988: Freezing point depression of NaCl-KCl- $\mathrm{H}_{2} \mathrm{O}$ solutions. Economic Geology 83, 197-202.

HELMY H.M., KAINDL R., FRITZ H., LOIZENBAUER J., 2004: The Sukari Gold Mine, Eastern Desert Egypt: structural setting, mineralogy and fluid inclusion study. Mineralium Deposita 39, 4, 495-511.

HURAI V., 1988: P-V-T-X tables of water and 1-25 weight percent $\mathrm{NaCl}-\mathrm{H}_{2} \mathrm{O}$ solutions to $500^{\circ} \mathrm{C}$ and $5000 \times 10^{5} \mathrm{~Pa}$. Acta Geologica et Geographica Universitatis Comenianae 44, 101-135.

JANÁK M., CHOVAN M., SMIRNOV A., MAJZLAN J., 2000. Kyanite and sillimanite in gneisses of the Ďumbier Crystalline Massif (Nízke Tatry Mts.). Mineralogy and Petrology Symposium, Magurka (in Slovak). 
KODĚRA M. (Ed.), 1990: Topographic mineralogy of Slovakia. Bratislava, VEDA (in Slovak).

KRETSCHMAR U., SCOTT S.D., 1976: Phase relations involving arsenopyrite in the system Fe-As-S and their application. Canadian Mineralogist 14, 364-386.

LAROCQUE A.C.L., HODGSON C.J., CABRI L.J., JACKMAN J.A., 1995: Ion-microprobe analysis of pyrite, chalcopyrite and pyrrhotite from the Mobrun VMS Deposit in the northwestern Quebec: Evidence for metamorphic remobilization of gold. Canadian Mineralogist 33, 373-388.

LUKÁČIK E., 1985: Petrography of granitoid rocks of the Nízke Tatry Pluton. Geologic Institute of Dionýz Štúr, Bratislava 95 pp. (in Slovak).

MAJZLAN J., CHOVAN M., 1997: Hydrothermal mineralization in the Mlynná Dolina Valley, Nizke Tatry Mts. Mineralia Slovaca 29, 149-158 (in Slovak).

MAKOVICKÝ E., 1989: Modular classification of sulfosalts - Current status - Definition and application of homologous series. Neues Jahrbuch Fur Mineralogie-Abhandlungen 160, 3, 269-297.

MIKUŠ T., CHOVAN M., 2003: Hydrothermal Sb-Au mineralization in the Strážovské Vrchy Mountains (Malá Magura, Western Carpathians). Geologica Carpathica 54, 4, 207-216.

MIŠÍK M., JABLONSKÝ J., 2000: Lower Triassic quartzites of the Western Carpathians: Transport directions, source of clastics. Geologica Carpathica 51, 4, 251-264.

MLADENOVA V., KERESTEDJAN T., DIMITROVA D., 2004: The Balkan mountains Paleozoic gold deposits. Bulletin of the Geological Society of Greece XXXVI, 424-433.

MOZGOVA N.N., BORTNIKOV N.S., TSEPIN A.I., BORODAEV Y.S., VRUBLEVSKAJA S.V., VYALSOV L.N., KUZMINA O.V., SIVTSOV A.V., 1983: Falkmanite, $\mathrm{Pb}_{5.4} \mathrm{Sb}_{3.6} \mathrm{~S}_{11}$ : New data and relationship with sulfantimonites of lead (Re-examination of type material from Bayerland Mine, Bavaria). Neues Jahrbuch Fur Mineralogie-Abhandlungen 147, 1, 80-98.

MUMIN A.H., FLEET M.E., CHRYSSOULIS S.L., 1994: Gold mineralization in As-rich mesothermal gold ores of the Bogosu-Prestea mining district of the Ashanti Gold Belt, Ghana: Remobilization of "invisible" gold. Mineralium Deposita 29, 445-460.

OBERTHÜR T., WEISER T., AMANOR J.A., CHRYSSOULIS S.L., 1997: Mineralogical sitting and distribution of gold in quartz veins and sulfide ores of the Ashanti mine and other deposits in the Ashanti belt of Ghana: genetic implications. Mineralium Deposita 32, 2-15.

ORVOŠOVÁ M., MAJZLAN J., CHOVAN M., 1998: Hydrothermal alteration of granitoid rocks and gneisses in the Dúbrava Sb-Au Deposit, Western Carpathians. Geologica Carpathica 49, 5, 377-387.

OZDÍN D., CHOVAN M., 1999: New mineralogical and paragenetic knowledge about siderite veins in the vicinity of Vyšná Boca, Nízke Tatry Mts. Slovak Geological Magazine 5, 4, 255-271.

ROEDDER E., 1984: Fluid inclusions. Reviews in Mineralogy 12, 644 pp.

SAHA I., VENKATESH A.S., 2002: Invisible gold within sulfides from the Archean Hutti-Maski schist belt, Southern India. Journal of Asian Earth Sciences 20, 5, 449-457.

SHEPHERD T.J., RANKIN A.H., ALDERTON D.H.M., 1985: A practical guide to fluid inclusion studies. London, Chapman and Hall, 239 pp.

SLAVKAY M., 1988: A regional map of raw material deposits and their prognoses. The Nízke Tatry Mts. Bratislava, Geological Institute of Dionýz Štúr, 350 pp. (in Slovak).

SMIRNOV A., 1999: Alluvial gold in Nižná Boca (Nízke Tatry Mts.). Mineralia Slovaca 31, 318.

SMIRNOV A., CHOVAN M., 2003: Heavy minerals in alluvial sediments of the Boca River (Nízke Tatry Mts., Slovakia). Slovak Geological Magazine 9, 4, 269-281.

TÓTH M., 1882: Minerals of Hungary. Miskolc, Herman Ottó Museum, 565 pp. (in Hungarian).

UEMOTO T., RIDLEY J., MIKUCKI E., GROVES D.I., KUSAKABE M., 2002: Fluid chemical evolution as a factor in controlling the distribution of gold at the Archean Golden Crown lode gold deposit, Murchison province, Western Australia. Economic Geology and the Bulletin of the Society of Economic Geologists 97, 6, 1227-1248.

VAUGHAN J.P., KYIN A., 2004: Refractory gold ores in Archaean greenstones, Western Australia: mineralogy, gold paragenesis, metallurgical characterization and classification. Mineralogical Magazine 68, 2, 255-277.

VOLKO-STAROHORSKÝ J., 1949: Geological evaluation of ore deposits in the Boca area in the Liptov Region. Slovak Central Geological Institute, Bratislava (in Slovak). 
VOZÁROVÁ A., VOZÁR J., 1988: Late Paleozoic in West Carpathians. Bratislava, Geologic Institute of Dionýz Štúr, 314 pp.

\author{
Alexander SMIRNOV, Jaroslav PRŠEK and Martin CHOVAN
}

\title{
Mineralogia i geochemia hydrotermalnego złoża Sb-Au Nižná Boca (Zachodnie Karpaty, Słowacja)
}

\section{Streszczenie}

Złoże hydrotermalne Sb-Au, położone na SE od wsi Nižná Boca w Małych Tatrach, było eksploatowane do końca XIX wieku. Sporządzono mapy wystąpienia żył rudnych, a próbki pobrano $\mathrm{z}$ licznych hałd. $\mathrm{W}$ badaniach laboratoryjnych zastosowano mikroskopię w świetle odbitym, mikrosondę elektronową dyfraktometrię rentgenowska, optyczną spektrometrię emisyjną, atomową spektroskopię absorpcyjną i analizę inkluzji ciekłych. Minerały kruszcowe są najczęściej zawarte w żyłach kwarcowo-węglanowych o przebiegu N-S, występujących w biotytowych granodiorytach-tonalitach typu I wieku waryscyjskiego (tzw. typ Ďumbierski). Paragenezy w złożu są zbliżone do innych przejawów mineralizacji tego samego typu w Niżnych Tatrach Ďumbierskich. Najstarszym jest etap kwarco-arsenopirytowy z pirytem, utworzony w temperaturach około $445^{\circ} \mathrm{C}$. Następnie tworzyły się żyły kwarcowo-węglanowo-antymonitowe z zinkenitem, a po nich żyły kwarcowo-węglanowo-sfalerytowo-galenowe z boulangerytem i złotem. Złoto zawiera przeważnie $9-18 \%$ wag. Ag, niezależnie od współwystępujących z nim minerałów. Nie znaleziono złota innych generacji, chociaż nie można wykluczyć, że część jego ziaren powstała w wyniku remobilizacji złota ze struktury złotonośnego arsenopirytu. Zawartość Au w rudzie waha się w granicach 0,53-20,2 g.t $\mathrm{t}^{-1}$, a Ag w granicach 0,9-31,2 g.t $\mathrm{t}^{-1}$. Najmłodszymi paragenezami kruszcowymi w złożu są tetraedryt $\mathrm{z}$ chalkopirytem oraz baryt $\mathrm{z}$ hematytem. Ciekłe inkluzje zawarte w minerałach reprezentujących pierwszy etap powstania złoża mają zwykle rozmiary poniżej $3 \mu \mathrm{m}$ i zawierają mniej niż 3,6\% wag. $\mathrm{CO}_{2}$; ich zasolenie, gęstość i temperatury homogenizacji wahają się odpowiednio w granicach $2,7-16,35 \%$ wag. $\mathrm{NaCl}_{(\mathrm{eq})}, 0,85-1,03 \mathrm{~g} \cdot \mathrm{cm}^{-1}$ i $128-280^{\circ} \mathrm{C}$. 